\title{
Preparation of Stimuli-responsive Polysilsesquioxane Grafted Block Copolymer of Acrylamide Monomers
}

\author{
By Toyoshi MASUdA, ${ }^{1}$ Shin-ichi YAMAMoto, ${ }^{1}$ Osamu MorIYA, ${ }^{1, *}$ Mikihiro KaSHIo, ${ }^{2}$ and Toshio SUGIZAKI ${ }^{2}$
}

The polysilsesquioxanes (PSQs) having the graft block copolymer of $N$-isopropylacrylamide (NIPAM) and $N, N$ dimethylacrylamide (DMAA), which showed the different sequence and number of the monomer units, were obtained by RAFT process. In addition, the PSQ derivatives containing other organic functional groups besides the grafted polymers were prepared by the use of chloromethylphenyl groups on the starting PSQ. Through the formation of ester bond and quarternary ammonium salt, phenol, triethylamine, and $N, N$-dimethylaniline groups were introduced into the grafted PSQ, respectively. In the behaviors of reversible thermoresponsive aggregation caused by poly(NIPAM) component, the almost same Lowest Critical Solution Temperature such as $34^{\circ} \mathrm{C}$ was observed for the grafted PSQs, although the poly(DMAA), phenol groups, and/or the quarternary ammonium salts were existed on the same PSQ backbone. As an additional function, the presence of phenol groups led to $\mathrm{pH}$ responsive solubility in water. The solubility of the PSQs in water was also affected by hydrophilic property of the amines to form the quarternary ammonium salts. In addition, a kind of chromism, which related with $\mathrm{pH}$ value, was observed in the case containing $N, N$-dimethylaniline moieties.

KEY WORDS: Thermoresponsive Phase Separation / Polysilsesquioxane / N-Isopropylacrylamide / Chromism / Graft Polymerization /

Recently, various investigations on oligomeric and polymeric silsesquioxanes, which stress on the modifications by various organic functional groups, have been presented from the interests in a useful hybrid material. ${ }^{1-9}$ The graft polymerization from polysilsesquioxane backbone is shown as an effective procedure for the modifications. The methodology enables to provide the additional functions based on the polymeric components without loosing the essential properties of inorganic siloxane structure such as durability for heat and weatherability. ${ }^{10-16}$ In the previous works, we also have investigated concerning the graft polymerizations from polysilsesquioxane backbone, which intended to develop the new multi-functional hybrid materials. ${ }^{17-21}$ As an example of such graftings, the introduction of block copolymer of $N, N$-dimethylacrylamide (DMAA) and $N$-isopropylacrylamide (NIPAM) by the living polymerization technique, reversible addition-fragmentation chain transfer (RAFT) process, was reported. $^{21}$ In the graft polymerization, the PSQ having chloromethylphenyl groups (CPPSQ) was prepared from the corresponding trimethoxysilane and, then, $N, N$-dimethyldithiocarbamate (DTC) group was introduced as a chain transfer specie for RAFT process.

The previous results demonstrated that the block copolymer grafted PSQs showed an expected amphiphilic property, where the solubility in water was influenced by the sequence and number of the monomer units in the grafted chain. ${ }^{21}$ Namely, when the more hydrophilic poly(DMAA) was grafted from the polysilsesquioxane backbone at first and poly(NIPAM) was grafted after poly(DMAA) component [poly(DMAA)-blockpoly(NIPAM)], hydrophilic property of the corresponding PSQ was effectively improved. When poly(NIPAM) was placed between PSQ backbone and poly(DMAA) [poly(NIPAM)-block-poly(DMAA)], the solubility in water was insufficient. Namely, the solubility of the grafted PSQs having poly(DMAA)-block-poly(NIPAM) in water was remarkably improved. Furthermore, the contact angles of the films, obtained from the grafted PSQs, suggested that the other expected property such as thermoresponsive phase separation was given by the grafted poly(NIPAM). ${ }^{22-27}$ However, the thermoresponsive behavior of the grafted PSQs, which was affected by the environment of poly(NIPAM), has not been examined in the report. ${ }^{21}$ The component of poly(DMAA), which presents more hydrophilic environment compared to the poly(NIPAM), in the block copolymer may raise Lowest Critical Phase Separation Temperature (LCST) as shown in the random copolymer prepared from the same monomers. ${ }^{28,29}$ While, no influence on the thermoresponsive behavior is observed on the gel containing the block copolymer of NIPAM. ${ }^{30}$ The examination concerning the behavior of the block copolymer grafted PSQs, in which the hydrophilic environment should be changed by sequence and molecular weight of the polymeric components, was expected to give the information concerning the phenomenon of thermoresponsive phase separation caused by poly(NIPAM).

The formation of a multi-functionalized PSQ, which expands the utility as the hybrid material, is another interesting theme. Fortunately, CPPSQ, chosen as the intermediary derivative for the graftation, contained reactive chloromethylphenyl groups. The utilization of the group for the formation of quarternary ammonium salt is a simple and practical method to provide various functions through the incorporation of organic moieties. In facts, several simple moieties were introduced by

\footnotetext{
${ }^{1}$ Department of Applied Chemistry, National Defense Academy, 1-10-20 Hashirimizu, Yokosuka 239-8686, Japan

${ }^{2}$ Research Laboratory, Lintec Co., Nishiki-cho, Warabi 335-0005, Japan

*To whom correspondence should be addressed (Tel: +81-46-841-3810, Ext. 2404; Fax: +81-46-844-5901, E-mail: moriyaos@ nda.ac.jp).
} 

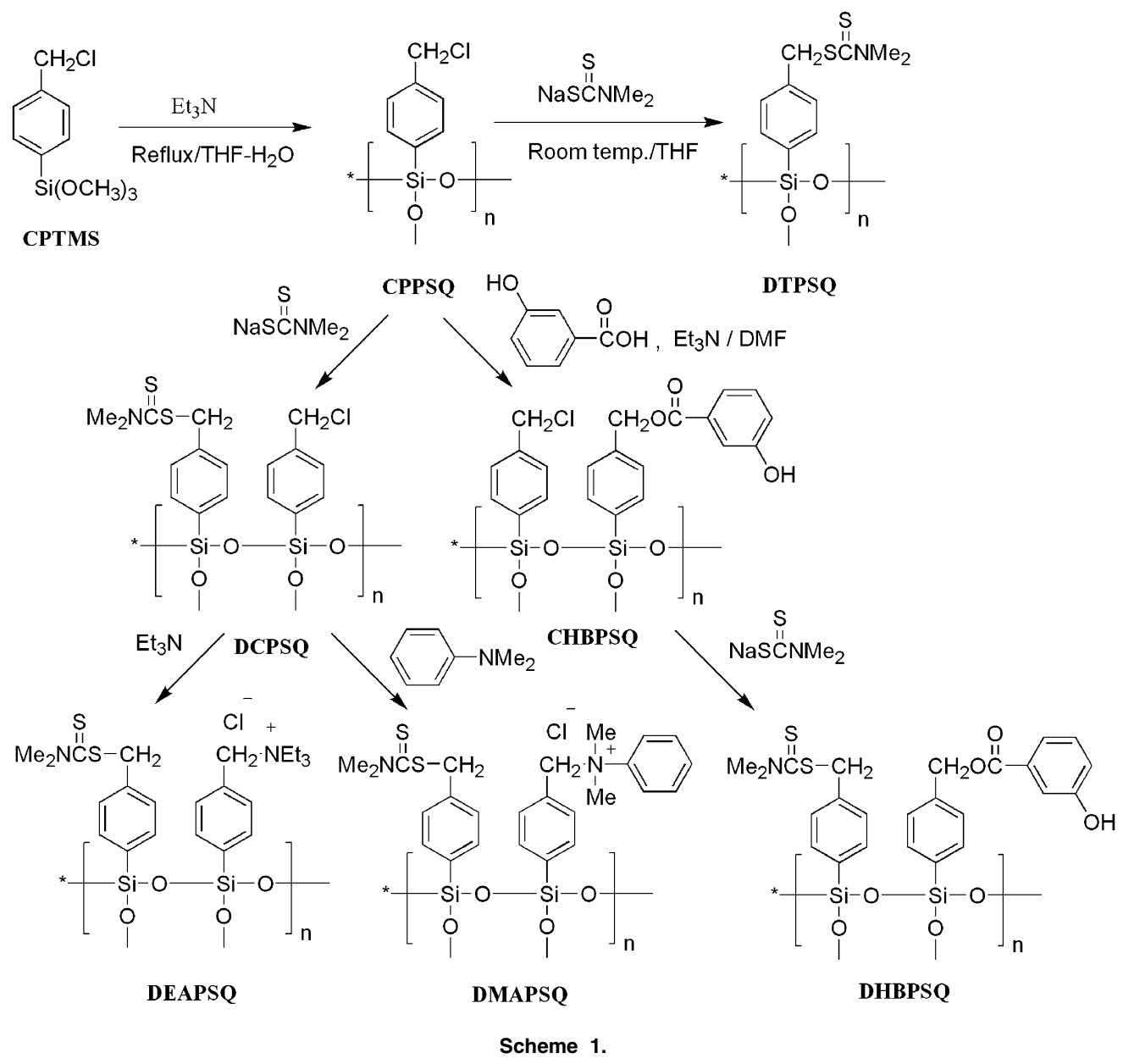

the formation of the salts in our previous work. ${ }^{20}$ Therefore, the PSQ having chloromethylphenyl groups is a convenient material for the preparation of multi-functional hybrid. As another example by the use of the group, the incorporation of functional group through the formation of ester bond was nominated in this work, since chloromethylphenyl group enabled an efficient reaction with carboxylic acid. As mentioned above, several grafted PSQs obtained in the previous work, which contained the different sequence and the molecular weight of polymeric components, were employed for the evaluation of thermoresponsivility. ${ }^{21}$ In addition, several PSQ derivatives, which had organic functional groups besides the graft copolymers, were newly prepared from the expectation to provide a multi-functionality. For the formations of quarternary ammonium salt, triethylamine or $\mathrm{N}, \mathrm{N}$-dimethylaniline was treated with chloromethylphenyl group on the PSQ backbone, respectively. As another trial to introduce a functional group, $m$-hydroxybenzoic acid was employed to incorporate phenol groups on the PSQ backbone. In this case, the PSQ having the graft chains and phenol groups was expected to show both $\mathrm{pH}$ responsive and thermoresponsive aggregation in an aqueous solution. Such evaluations on the properties of the multifunctional derivatives are thought to afford the information on a multiple characteristic, which is helpful to design a new and a useful hybrid material based on PSQ. The synthetic routes of the PSQs mentioned here were shown in Schemes 1 and 2.

\section{EXPERIMENTAL}

\section{General}

${ }^{1} \mathrm{H}$ NMR and ${ }^{13} \mathrm{C}$ NMR spectra were obtained on a JEOL AL-300 and JNM A-500 spectrometer in $\mathrm{CDCl}_{3}$ or DMF-d $\mathrm{d}_{7}$. IR spectra were recorded on a JASCO FT/IR 230. Gel permeation chromatographic (GPC) analysis was carried out to estimate number-average molecular weight $\left(M_{\mathrm{n}}\right)$ and polydispersity $\left(M_{\mathrm{w}} / M_{\mathrm{n}}\right)$ on a Shimadzu LC-10VP chromatograph equipped with an evaporative light scattering detector. Three columns such as Shim-pack GPC-80MD, -804D, and -802D were connected in series and $N, N$-dimethylformamide (DMF) was used as an eluent. Calibration was performed using poly(methyl methacrylate) standards. DMF employed for the reactions was refluxed over calcium hydride and distilled. Ethanol was treated with sodium and magnesium metal before use. Tetrahydrofurane (THF) was refluxed over sodium metal before use. NIPAM was recrystallized from the mixed solvent of benzene and $n$-hexane. DMAA was distilled over calcium hydride before use. $N, N^{\prime}$-azobisisobutyronitrile (AIBN) was recrystallized from methanol. Other reagents including (4- 


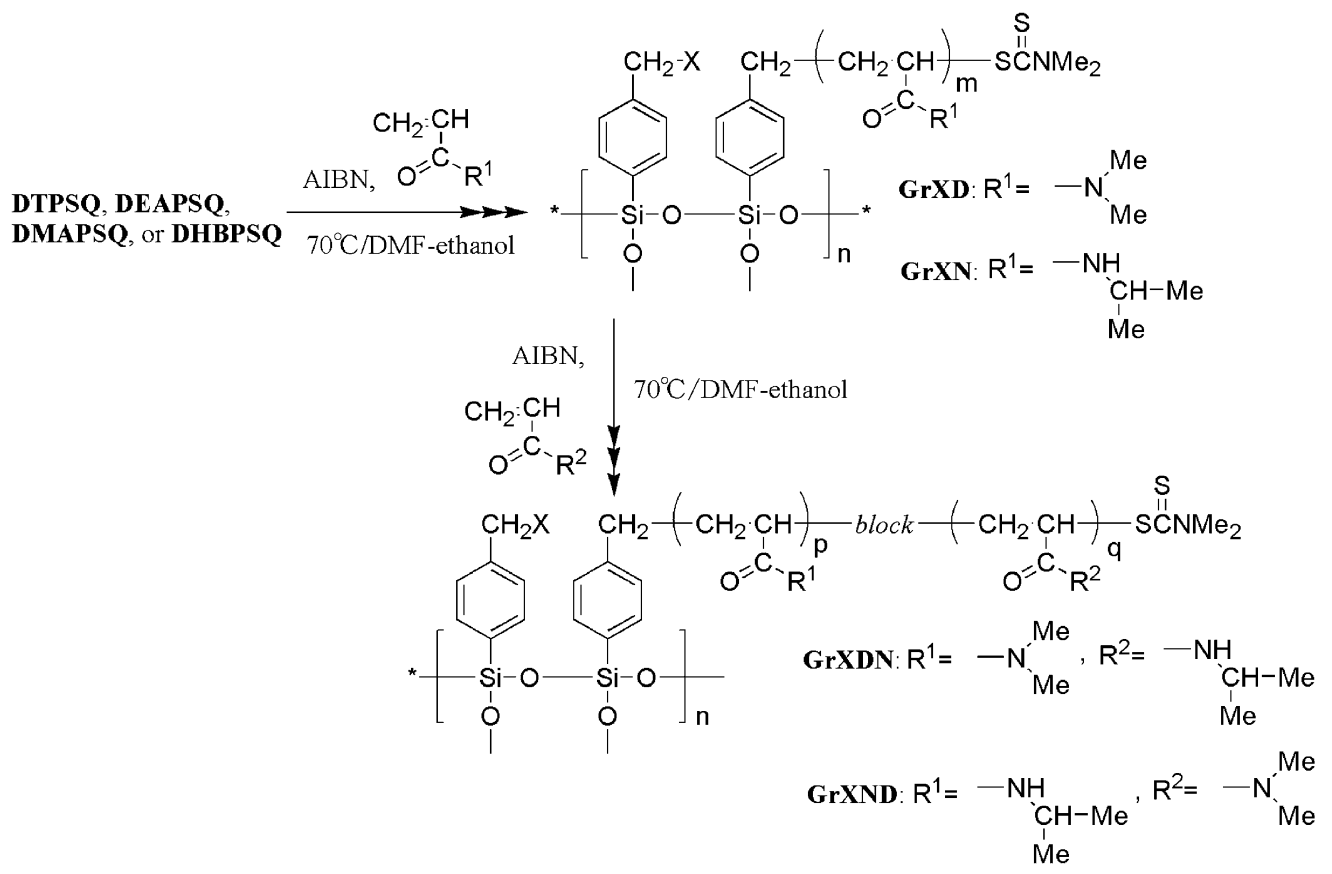

X=None: Poly(DMAA), Poly(NIPAM), Poly(DMAA)-block-Poly(NIPAM) or Poly(NIPAM)-block-Poly(DMAA)

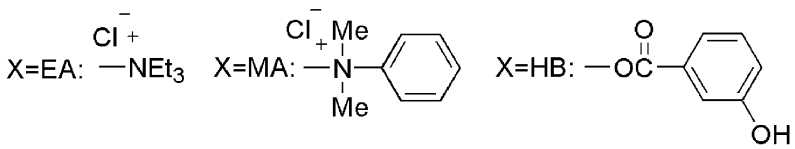

Scheme 2.

chloromethyl)phenyltrimethoxysilane (TCI, 98\%), and $\mathrm{N}, \mathrm{N}$ dimethyldithiocarbamic acid sodium salt dihydrate (TCI, 98\%) were used as supplied from commercial sources.

The preparations of the PSQs having chloromethylphenyl groups (CPPSQ), DTC groups (DTPSQ), and the grafted PSQs containing block and random copolymers of NIPAM and DMAA were reported in the previous work. ${ }^{21}$ The PSQs newly prepared in this work were depicted as follows.

\section{Preparation of $P S Q$ Having DTC Group and Quarternary Ammonium Salt}

A solution of CPPSQ (2.00 g, chloromethyl group: 9.6 mmol equiv.) and sodium $N, N$-dimethyldithiocarbamate dihydrate $(0.96 \mathrm{~g}, 6.74 \mathrm{mmol})$ in THF $(20 \mathrm{~mL})$ was stirred at $30{ }^{\circ} \mathrm{C}$ for $8 \mathrm{~h}$. The resulting solution was evaporated under reduced pressure to concentrate and the residue was poured into methanol. The insoluble solid was collected and washed with water and methanol. After drying at room temperature for $24 \mathrm{~h}$ under reduced pressure $(<5 \mathrm{mmHg})$, the PSQ having chloromethyl and DTC groups (DCPSQ) was obtained (2.40 g, 96\% yield based on substituted methylphenyl group).

Next, to a solution of DCPSQ (1.00 g, Chloromethyl group: 1.4 mmol equiv., DTC group: $2.7 \mathrm{mmol}$ equiv.) in DMF (3.2 $\mathrm{mL})$, triethylamine $(0.17 \mathrm{~g}, 1.72 \mathrm{mmol})$ was added under argon atmosphere and stirred at $50{ }^{\circ} \mathrm{C}$ for $18 \mathrm{~h}$. The resulting solution was poured into diethyl ether to precipitate the product. The insoluble solid was collected and dried at room temperature for $24 \mathrm{~h}$ under reduced pressure $(<5 \mathrm{mmHg})$ to obtain the PSQ having DTC groups and the quarternary ammonium salts of triethylamine (DEAPSQ, $1.07 \mathrm{~g}$, 95\% yield based on the substituted methylphenyl group). The contents of chloromethyl and DTC groups in DCPSQ and DEAPS were calculated from the peak areas observed in ${ }^{1} \mathrm{H}$ NMR spectrum, in which hexamethyldisiloxane was used as an internal standard: DCPSQ; IR (KBr) 3427, 2928, 2925, 1495, 1376, 1256, 1127 (Si-O), 982, $700 \mathrm{~cm}^{-1} ;{ }^{1} \mathrm{H}$ NMR (DMF-d $\left.{ }_{7}, 300 \mathrm{MHz}\right) \delta$ 6.89-7.35 (br m, - $\mathrm{C}_{6} \underline{\mathrm{H}}_{4}-$ ); 4.70 (br, $\mathrm{ClC}_{2}-\mathrm{C}_{6} \mathrm{H}_{4}-$ ), 4.50 (br, $\left.-\mathrm{S}-\mathrm{CH}_{2}-\mathrm{C}_{6} \mathrm{H}_{4}-\right), 3.43$ (br, N-C $\left.\underline{\mathrm{H}}_{3}\right), 3.33\left(\mathrm{br}, \mathrm{N}-\mathrm{CH}_{3}\right) ;{ }^{13} \mathrm{C} \mathrm{NMR}$ $\left(\mathrm{CDCl}_{3}, 125 \mathrm{MHz}\right) \quad \delta \quad 196.3 \quad(\underline{\mathrm{C}}=\mathrm{S}) ; 134.1 \quad\left(-\underline{\mathrm{C}}_{6} \mathrm{H}_{4}-\right), 128.7$ $\left(-\underline{\mathrm{C}}_{6} \mathrm{H}_{4}^{-}\right), 45.8\left(\mathrm{ClCH}_{2}-\mathrm{C}_{6} \mathrm{H}_{4}^{-}\right), 45.3\left(-\mathrm{S}-\underline{\mathrm{CH}}_{2}-\mathrm{C}_{6} \mathrm{H}_{4}{ }^{-}\right), 42.5$ $\left(\mathrm{N}-\underline{C H}_{3}\right), \quad 41.5 \quad\left(\mathrm{~N}-\underline{C H}_{3}\right) ; \quad M_{\mathrm{n}}=4000, \quad M_{\mathrm{w}} / M_{\mathrm{n}}=1.21$. DEAPSQ; IR (KBr) 3403, 3050, 2926, 1497, 1376, 1256, 1129 (Si-O), 982, 776, $706 \mathrm{~cm}^{-1} ;{ }^{1} \mathrm{H}$ NMR (DMF-d $\left.7,300 \mathrm{MHz}\right) \delta$ 6.89-7.91 (br m, - $\mathrm{C}_{6} \underline{\mathrm{H}}_{4}-$ ); 4.67 (br, $\mathrm{N}^{+}-\mathrm{CH}_{2}-\mathrm{C}_{6} \mathrm{H}_{4}-$ ), 4.50 (br, $-\mathrm{S}-\underline{\mathrm{C}}_{2}-\mathrm{C}_{6} \mathrm{H}_{4}-$ ), 3.43 (br, N-C $\underline{\mathrm{H}}_{3}, \mathrm{~N}^{+}-\mathrm{C}_{2} \mathrm{CH}_{3}$ ), 3.33 (br, N$\left.\mathrm{CH}_{3}\right), 1.37$ (br, $\left.-\underline{\mathrm{CH}}_{3}\right) ;{ }^{13} \mathrm{C} \mathrm{NMR}\left(\mathrm{CDCl}_{3}, 125 \mathrm{MHz}\right) \delta 200.0$ $(\underline{\mathrm{C}}=\mathrm{S}), 138.9\left(-\underline{\mathrm{C}}_{6} \mathrm{H}_{4}-\right), 133.6\left(-\underline{\mathrm{C}}_{6} \mathrm{H}_{4}-\right), 52.3\left(\mathrm{~N}^{+}-\underline{\mathrm{CH}}_{2} \mathrm{CH}_{3}\right)$, $45.9\left(-\mathrm{S}-\mathrm{CH}_{2}-\mathrm{C}_{6} \mathrm{H}_{4}^{-}, \mathrm{N}^{+}-\mathrm{CH}_{2}-\mathrm{C}_{6} \mathrm{H}_{4}-\right), 41.5\left(\mathrm{~N}-\underline{C H}_{3}\right), 12.5$ $\left(-\mathrm{CH}_{3}\right) ; M_{\mathrm{n}}=5000, M_{\mathrm{w}} / M_{\mathrm{n}}=1.17$.

Analogously, from DCPSQ $(1.00 \mathrm{~g}$, chloromethyl group: $1.4 \mathrm{mmol}$ equiv., DTC group: $2.7 \mathrm{mmol}$ equiv.) and $N, N$ dimethylaniline $(0.21 \mathrm{~g}, 1.72 \mathrm{mmol})$, the PSQ having DTC 
groups and the corresponding quarternary ammonium salts (DMAPSQ, $0.99 \mathrm{~g}, \quad 86 \%$ yield based on the substituted methylphenyl group) was obtained: IR (KBr) 3425, 3023, 2927, 1503, 1375, 1256, 1129 (Si-O), 984, 691, $522 \mathrm{~cm}^{-1}$; ${ }^{1} \mathrm{H}$ NMR (DMF-d 7 , $\left.300 \mathrm{MHz}\right) \delta 6.45-7.83$ (br m, $-\mathrm{C}_{6} \underline{\mathrm{H}}_{4}-$ ), 4.65 (br, $\mathrm{N}^{+}-\mathrm{CH}_{2}-\mathrm{C}_{6} \mathrm{H}_{4}-$ ), 4.50 (br, -S- $\underline{\mathrm{H}}_{2}-\mathrm{C}_{6} \mathrm{H}_{4}-$ ), 3.43 (br, -N$\left.\mathrm{CH}_{3}, \quad \mathrm{~N}^{+}{ }_{-} \underline{\mathrm{C}}_{3}\right), \quad 3.33$ (br, $\left.-\mathrm{N}-\mathrm{CH}_{3}, \quad \mathrm{~N}^{+}-\mathrm{CH}_{3}\right) ; \quad{ }^{13} \mathrm{C} \mathrm{NMR}$ $\left(\mathrm{CDCl}_{3}, 125 \mathrm{MHz}\right) \delta 196.4(\underline{\mathrm{C}}=\mathrm{S}), 138.7\left(-\mathrm{C}_{6} \mathrm{H}_{4}-, \mathrm{N}^{+}-\underline{\mathrm{C}}_{6} \mathrm{H}_{5}\right)$, $134.1\left(-\underline{C}_{6} \mathrm{H}_{4}-, \mathrm{N}^{+}-\underline{\mathrm{C}}_{6} \mathrm{H}_{5}\right), 128.6\left(-\mathrm{C}_{6} \mathrm{H}_{4}-, \mathrm{N}^{+}-\mathrm{C}_{6} \mathrm{H}_{5}\right), 45.8$ (-S$\left.\mathrm{CH}_{2}-\mathrm{C}_{6} \mathrm{H}_{4}^{-}\right), 42.9\left(-\mathrm{N}-\underline{C H}_{3}, \mathrm{~N}^{+}-\underline{C H}_{3}\right), 41.4\left(-\mathrm{N}-\underline{C H}_{3}, \mathrm{~N}^{+}\right.$ $\left.\mathrm{CH}_{3}\right) ; M_{\mathrm{n}}=5000, M_{\mathrm{w}} / M_{\mathrm{n}}=1.21$.

\section{Preparation of $P S Q$ Having Phenol Group}

To a solution of CPPSQ (1.00 g, chloromethyl group: 4.8 mmol equiv.) and $m$-hydroxybenzoic acid $(0.27 \mathrm{~g}, 1.92 \mathrm{mmol})$ in DMF $(4 \mathrm{~mL})$, triethylamine $(0.17 \mathrm{~g}, 1.70 \mathrm{mmol})$ was added. The solution was stirred at $50{ }^{\circ} \mathrm{C}$ for $8 \mathrm{~h}$. The resulting mixture was poured into diethyl ether. The insoluble solid was collected and washed with water and diethyl ether. The solid was dried at room temperature for $24 \mathrm{~h}$ under reduced pressure $(<5 \mathrm{mmHg})$ to obtain the PSQ having chloromethylphenyl and phenol groups (CHBPSQ) $(0.61 \mathrm{~g}, 52 \%$ yield based on substituted methylphenyl group); IR ( $\mathrm{KBr}) 3399(\mathrm{OH}), 3221,1714(\mathrm{C}=\mathrm{O})$, 1601, 1452, 1396, 1286, 1130 (Si-O), 758, $690 \mathrm{~cm}^{-1} ;{ }^{1} \mathrm{H}$ NMR $\left(\mathrm{DMF}_{-} \mathrm{d}_{7}, 300 \mathrm{MHz}\right) \delta 7.38-6.62$ (br m, $\left.-\mathrm{C}_{6} \underline{\mathrm{H}}_{4}-,-\mathrm{C}_{6} \underline{\mathrm{H}}_{4}-\mathrm{OH}\right)$, 5.27 (br, $\left.-\mathrm{CH}_{2}-\mathrm{O}-\mathrm{C}=\mathrm{O}-\right)$, 4.66 (br, $\left.\mathrm{ClCH}_{2}-\mathrm{C}_{6} \mathrm{H}_{4}-\right) ;{ }^{13} \mathrm{C}-\mathrm{NMR}$ $\left(\mathrm{CDCl}_{3}, 125 \mathrm{MHz}\right) \delta 165.2(-\mathrm{O}-\underline{\mathrm{C}}=\mathrm{O}-), 157.5\left(-\underline{\mathrm{C}}_{6} \mathrm{H}_{4}-\mathrm{OH}\right)$, $133.5\left(-\underline{C}_{6} \mathrm{H}_{4}{ }^{-},-\underline{\mathrm{C}}_{6} \mathrm{H}_{4}-\mathrm{OH}\right), 127.6\left(-\underline{\mathrm{C}}_{6} \mathrm{H}_{4}{ }^{-},-\underline{\mathrm{C}}_{6} \mathrm{H}_{4}-\mathrm{OH}\right), 126.6$ $\left(-\underline{\mathrm{C}}_{6} \mathrm{H}_{4}-,-\underline{\mathrm{C}}_{6} \mathrm{H}_{4}-\mathrm{OH}\right), 119.9\left(-\underline{\mathrm{C}}_{6} \mathrm{H}_{4}-\mathrm{OH}-\right), 65.2\left(-\underline{\mathrm{CH}}_{2}-\mathrm{O}-\mathrm{C}=\right.$ O- $), 45.0\left(\mathrm{Cl}-\mathrm{CH}_{2}-\mathrm{C}_{6} \mathrm{H}_{4}-\right) ; M_{\mathrm{n}}=5000, M_{\mathrm{w}} / M_{\mathrm{n}}=1.15$.

Analogpusly, CHBPSQ (0.46 g, chloromethyl group: 1.3 mmol equiv.) was treated with sodium $N, N$-dimethyldithiocarbamate dihydrate $(0.24 \mathrm{~g}, 1.70 \mathrm{mmol})$ in THF $(10 \mathrm{~mL})$ to obtain the PSQ having phenol and DTC groups (DHBPSQ, $0.53 \mathrm{~g}, 94 \%$ yield based on substituted methylphenyl group); IR (KBr) $3427(\mathrm{OH}), 2929\left(\mathrm{C}_{6} \mathrm{H}_{5}\right), 1714$ (-O-C=O-), 1602, 1500, 1454, 1376, 1289 (-O-C=O-C $\left.\mathrm{H}_{4}-\right), 1130$ ( $\left.\mathrm{Si}-\mathrm{O}\right), 981$, $873,809,758,688 \mathrm{~cm}^{-1} ;{ }^{1} \mathrm{H}$ NMR (DMF-d $\left.7,300 \mathrm{MHz}\right) \delta$ 7.61-6.81 (br m, - $\mathrm{C}_{6} \underline{\mathrm{H}}_{4}-,-\mathrm{C}_{6} \underline{\mathrm{H}}_{4}-\mathrm{OH}$ ), 5.27 (br, $-\mathrm{CH}_{2}-\mathrm{O}-\mathrm{C}=\mathrm{O}-$ ), 4.47 (br, -S- $\underline{\mathrm{CH}}_{2}-\mathrm{C}_{6} \mathrm{H}_{4}-$ ), 3.44 (br, $-\mathrm{N}-\mathrm{CH}_{3}$ ), 3.31 (br, $-\mathrm{N}-\mathrm{CH}_{3}$ ); ${ }^{13} \mathrm{C} \mathrm{NMR} \quad\left(\mathrm{CDCl}_{3}, \quad 125 \mathrm{MHz}\right) \quad \delta \quad 194.5 \quad(-\mathrm{C}=\mathrm{S}), \quad 165.2$ (-O-C $=\mathrm{O}-), 161.7 \quad\left(-\underline{\mathrm{C}}_{6} \mathrm{H}_{4}-\mathrm{OH}\right), 133.4\left(-\underline{\mathrm{C}}_{6} \mathrm{H}_{4}-,-\underline{\mathrm{C}}_{6} \mathrm{H}_{4}-\mathrm{OH}\right)$, $130.4\left(-\underline{\mathrm{C}}_{6} \mathrm{H}_{4} 4^{-},-\underline{\mathrm{C}}_{6} \mathrm{H}_{4}-\mathrm{OH}\right), 130.0\left(-\underline{\mathrm{C}}_{6} \mathrm{H}_{4} 4^{-},-\underline{\mathrm{C}}_{6} \mathrm{H}_{4}-\mathrm{OH}\right), 126.6$ $\left(-\mathrm{C}_{6} \mathrm{H}_{4}-,-\underline{\mathrm{C}}_{6} \mathrm{H}_{4}-\mathrm{OH}-\right), 120.0\left(-\mathrm{C}_{6} \mathrm{H}_{4}-\mathrm{OH}\right), 66.2\left(-\mathrm{CH}_{2}-\mathrm{O}-\mathrm{C}=\right.$ $\mathrm{O}-), 44.1\left(-\mathrm{S}-\underline{\mathrm{CH}}_{2}-\mathrm{C}_{6} \mathrm{H}_{4}-\right), 42.3\left(-\mathrm{N}-\underline{\mathrm{CH}}{ }_{3}\right), 41.3\left(-\mathrm{N}-\underline{C H}_{3}\right)$; $M_{\mathrm{n}}=5000, M_{\mathrm{w}} / M_{\mathrm{n}}=1.15$.

\section{Typical Procedure for Grafting of Block Copolymer}

A solution of DEAPSQ $(0.12 \mathrm{~g}$, DTC group: $0.3 \mathrm{mmol}$ equiv.), DMAA $(0.59 \mathrm{~g}, 6.00 \mathrm{mmol})$, and AIBN (0.008 g, $0.05 \mathrm{mmol})$ in the mixed solvents of DMF $(2.0 \mathrm{~mL})$ and ethanol $(1.0 \mathrm{~mL})$ was introduced into a glass tube. The mixture was purged of air via three vacuum-argon cycles. Then, the mixture in the glass tube was heated at $70^{\circ} \mathrm{C}$ for $8 \mathrm{~h}$ under argon atmosphere. The resulting solution was evaporated under reduced pressure to concentrate and the residue was poured into diethyl ether. The insoluble solid was collected and dried at room temperature for $24 \mathrm{~h}$ under reduced pressure $(<5 \mathrm{mmHg})$ to obtain the poly(DMAA) grafted PSQ (GrEAD2) (0.65 g, 92\% yield based on weight).

The grafting of the second monomer, NIPAM, to GrEAD2 was carried out under the similar conditions mentioned above. For the graft polymerization, the amount of NIPAM was adjusted to be 10 equiv. to DTC group in GrEAD2. The PSQ having poly(DMAA)-block-poly(NIPAM) as the graft chains with the ammonium salts (GrEAD2N) was isolated as an insoluble solid from diethyl ether in $93 \%$ yield based on weights of the substrates. The contents of DTC group, ammonium salt, and the monomer units in the products were calculated from the peak areas observed in ${ }^{1} \mathrm{H}$ NMR spectrum, in which hexamethyldisiloxane was used as an internal standard: GrEAD2N; IR (KBr) 3443, 2966, 2933, 1631 $(\mathrm{C}=\mathrm{O}), 1547,1460,1400,1139(\mathrm{Si}-\mathrm{O}), 1093,671 \mathrm{~cm}^{-1}$; ${ }^{1} \mathrm{H}$ NMR $\left(\mathrm{CDCl}_{3}\right) \delta$ 6.09-7.89 (br m, $\left.-\mathrm{C}_{6} \underline{\mathrm{H}}_{4}-\right), 4.70$ (br, $\mathrm{N}^{+}$. $\mathrm{C}_{2}-\mathrm{C}_{6} \mathrm{H}_{4}$ ), 3.86 (br, -NH-C $\underline{\mathrm{H}}-$ ), 3.49 (br, -(C=S)-N-C $\left.\underline{\mathrm{H}}_{3}\right)$, 3.31 (br, - $(\mathrm{C}=\mathrm{S})-\mathrm{N}-\underline{\mathrm{C}}_{3}, \mathrm{~N}^{+}-\mathrm{C}_{2} \mathrm{CH}_{3}$ ), 2.70-3.05 (br m, N$\left.\mathrm{CH}_{3}\right), 2.20-2.70$ (br, $\left.-(\mathrm{C}=\mathrm{O})-\mathrm{CH}-,-\mathrm{CH}_{2}-\mathrm{C}_{6} \mathrm{H}_{4}-\right), 1.45-1.80$ (br m, $-\mathrm{C}_{2}-$ ), $1.05-1.30$ (br m, $-\mathrm{C}_{3}$ ); ${ }^{13} \mathrm{C} \mathrm{NMR}(125 \mathrm{MHz}$, $\left.\mathrm{CDCl}_{3}\right) \delta 174.4(-\underline{\mathrm{C}}=\mathrm{O}), 133.9\left({ }^{-} \underline{\mathrm{C}}_{6} \mathrm{H}_{4}{ }^{-}\right), 128.5\left(-\underline{\mathrm{C}}_{6} \mathrm{H}_{4}{ }^{-}\right), 42.3$ $(-\mathrm{N}-\underline{\mathrm{CH}}-), 37.3\left(\mathrm{~N}-\underline{\mathrm{CH}}_{3}\right), 36.1$ (- $\left.\underline{\mathrm{CH}}-\right), 35.7 \quad\left(-\underline{\mathrm{CH}}_{2}-\right), 22.4$ $\left(-\mathrm{CH}_{3}\right), 11.2\left(-\mathrm{CH}_{3}\right)$.

Analogously, from DMAPSQ and 20 equiv. of DMAA to DTC group, the grafted PSQ having $N, N$-dimethylaniline moieties (GrMAD2) was obtained in 94\% yield. The grafting of 10 equiv. of NIPAM to GrMAD2 also conducted to afford the corresponding PSQ (GrMAD2N) in 91\% yield: GrMAD2N; IR (KBr) 3442, 2980, $1631(\mathrm{C}=\mathrm{O}), 1542,1458$, 1141 (Si-O), 1098, $624 \mathrm{~cm}^{-1} ;{ }^{1} \mathrm{H}$ NMR $\left(\mathrm{CDCl}_{3}, 300 \mathrm{MHz}\right) \delta$ 6.50-7.72 (br m, $-\mathrm{C}_{6} \underline{\mathrm{H}}_{4}-$ ), 4.70 (br, $\mathrm{N}^{+}-\mathrm{C}_{2}-\mathrm{C}_{6} \mathrm{H}_{4}$ ), 3.86 (br, -NH-C $\underline{\mathrm{H}}-)$, 3.50 (br, - $\left.(\mathrm{C}=\mathrm{S})-\mathrm{N}-\mathrm{C}_{3}\right), 3.31$ (br, $-(\mathrm{C}=\mathrm{S})-\mathrm{N}-\mathrm{CH}_{3}$, $\mathrm{N}^{+}-\mathrm{C}_{3}$ ), 2.70-3.07 (br m, N-C $\underline{H}_{3}$ ), 2.20-2.70 (br, $-(\mathrm{C}=\mathrm{O}$ )-

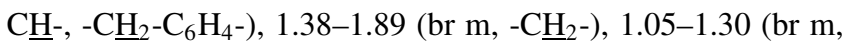
$\left.-\underline{\mathrm{C}}_{3}\right) ;{ }^{13} \mathrm{C}$ NMR $\left(125 \mathrm{MHz}, \mathrm{CDCl}_{3}\right) \delta 174.7$ (- $\left.\underline{\mathrm{C}}=\mathrm{O}\right), 134.1$ $\left(-\underline{\mathrm{C}}_{6} \mathrm{H}_{4}{ }^{-}\right), 128.6\left(-\underline{\mathrm{C}}_{6} \mathrm{H}_{4}{ }^{-}\right), 42.3$ (-NH- $\left.\underline{\mathrm{CH}}-\right), 37.3\left(\mathrm{~N}^{-} \underline{\mathrm{CH}}_{3}\right), 36.1$ (- $\underline{\mathrm{CH}}-), 35.7\left(-\mathrm{CH}_{2}-\right), 22.4\left(-\mathrm{C}_{3}\right)$.

Analogously, the graftings of 10 equiv. of NIPAM, used as the first monomer, onto DEAPSQ or DMAPSQ were conducted to obtain the corresponding products (GrEAN or GrMAN), respectively. Then, 20 equiv. of DMAA to DTC group were grafted onto each GrEAN and GrMAN as the second step to obtain the corresponding PSQs having poly(NIPAM)-block-poly(DMAA) graft chains (GrEAND2 and GrMAND2).

DHBPSQ was also treated with 20 equiv. of DMAA and 10 equiv. of NIPAM to DTC group under the same conditions mentioned above. The PSQs having poly(DMAA)-blockpoly(NIPAM) graft chains (GrHBD2N) and poly(NIPAM)block-poly(DMAA) graft chains (GrHBND2) were obtained as desired; GrHBD2N; IR (KBr) 3447 (N-H), 2970, 2933, 1632 $(\mathrm{C}=\mathrm{O}), 1546,1460,1400,1368,1257,1141,1093,629 \mathrm{~cm}^{-1}$; ${ }^{1} \mathrm{H} \mathrm{NMR}\left(\mathrm{CDCl}_{3}, 300 \mathrm{MHz}\right) \delta 7.61-6.81$ (br m, $-\mathrm{C}_{6} \underline{\mathrm{H}}_{4}^{-}$, $-\mathrm{C}_{6} \underline{\mathrm{H}}_{4}-\mathrm{OH}$ ), 5.27 (br, $-\mathrm{CH}_{2}-\mathrm{O}-\mathrm{C}=\mathrm{O}-$ ), 3.86 (br, -NH-C $\underline{H}_{-}$), 
Table I. Preparation of functional PSQ

\begin{tabular}{ccccc}
\hline Product & $\begin{array}{c}\text { Yield }^{\mathrm{a}} \\
\%\end{array}$ & $\begin{array}{c}\text { Content of } \\
\text { chloromethyl group } \\
\text { mmol equiv./g }\end{array}$ & $\begin{array}{c}\text { Content of } \\
\text { DTC group } \\
\text { mmol equiv./g }\end{array}$ & $\begin{array}{c}\text { Content of } \\
\text { functional group } \\
\text { mmol equiv./g }\end{array}$ \\
\hline DCPSQ & 96 & 1.4 & 2.7 & - \\
DEAPSQ & 95 & - & 2.6 & 1.2 \\
DMAPSQ & 86 & - & 2.5 & 1.1 \\
CHBPSQ & 52 & 2.7 & - & 1.6 \\
DHBPSQ & 94 & - & 2.2 & 1.5 \\
\hline
\end{tabular}

a Based on the content of phenyl group. ${ }^{b}$ Estimated by ${ }^{1} \mathrm{H}$ NMR spectral data.

3.42 (br, $-\mathrm{N}-\mathrm{CH}_{3}$ ), 3.24 (br, $-\mathrm{N}-\mathrm{CH}_{3}$ ), 3.05-2.70 (br m, -N$\mathrm{CH}_{3}$ ), 2.70-2.20 (br, $\left.-(\mathrm{C}=\mathrm{O})-\mathrm{C} \underline{\mathrm{H}}-,-\mathrm{C}_{2}-\mathrm{C}_{6} \mathrm{H}_{4}-\right), 1.80-1.45$ (br m, $-\underline{\mathrm{CH}}_{2}-$ ), $1.30-1.05$ (br m, $\left.-\underline{\mathrm{CH}}_{3}\right) ;{ }^{13} \mathrm{C}-\mathrm{NMR}\left(\mathrm{CDCl}_{3}\right.$, $125 \mathrm{MHz}) \delta 174.6(-\mathrm{C}=\mathrm{O}), 134.2\left(-\underline{\mathrm{C}}_{6} \mathrm{H}_{4^{-}},-\underline{\mathrm{C}}_{6} \mathrm{H}_{4}-\mathrm{OH}\right), 128.6$ $\left(-\underline{\mathrm{C}}_{6} \mathrm{H}_{4}-,-\underline{\mathrm{C}}_{6} \mathrm{H}_{4}-\mathrm{OH}\right), 41.2$ (-NH- $\left.\underline{\mathrm{CH}}-\right), 37.3\left(-\mathrm{N}-\underline{\mathrm{CH}}_{3}\right), 36.4$ (- $\underline{\mathrm{CH}}-), 35.6\left(-\mathrm{CH}_{2}-\right), 22.4\left(-\mathrm{CH}_{3}\right)$.

The results of those syntheses were listed in Tables I and II.

Measurement of Transmittance $(\% \mathrm{~T})$ for Solubility in Water, Thermoresponsive Behavior, and Chromism

$1 \mathrm{wt} \%$ solution of the grafted PSQ in deionized water was used for the measurement of transmittance (\% T) on a Shimadzu UV-1650 spectrophotometer equipped with a Peltier-type S-1700 thermostatic cell holder, where the changes of $\% \mathrm{~T}$ were observed from a visible source at $600 \mathrm{~nm}$ through a $1 \mathrm{~cm}$ quartz sample cell during heating and cooling scans. The rate of heating and cooling was adjusted to be $1{ }^{\circ} \mathrm{C} / 30 \mathrm{~s}$. The cycle of heating and cooling was repeated three times for a sample, in which almost same curves indicating the thermoresponsive behavior were observed. The value indicating solubility in water was the $\% \mathrm{~T}$ observed at $20^{\circ} \mathrm{C}$. In the measurements for the PSQs containing the ammonium salts obtained from $N, N$-dimethylaniline, ethanol was added as a co- solvent. The volume ratio of ethanol/water was adjusted to be $1 / 9$ in the mixed solvents. The UV absorption of GrMAND2 in the mixed solvent of water and ethanol was measured at $20^{\circ} \mathrm{C}$ by adjusting the $\mathrm{pH}$ values to 3,7 , and 11 . In the adjustments of $\mathrm{pH}$ value of the aqueous solutions, $1 \mathrm{~N} \mathrm{HCl}$ was used for $\mathrm{pH}=3$ and $\mathrm{NaOH}$ for $\mathrm{pH}=11$ and 12 .

\section{RESULTS AND DISCUSSION}

\section{Preparation of Grafted $P S Q$ Having Functional Group}

In the previous report, the PSQ having DTC groups was shown to be effective for the grafting of block copolymer of NIPAM and DMAA through RAFT process. ${ }^{21}$ For the introduction of DTC group, chloromethylphenyl group on PSQ backbone was usable. The presence of such reactive benzylchloride group enables a ready introduction of various organic moieties, which leads to the preparation of multifunctional PSQ derivatives. One of simple and convenient procedures was the formation of quaternary ammonium salt by the treatment with amines. ${ }^{31}$ As the examples for proving the functionalities, triethylamine and $\mathrm{N}, \mathrm{N}$-dimethylaniline were employed to form the qurternary ammonium salt moieties on PSQ backbone.

At first, the reaction of CPPSQ and sodium $N, N$-dimethyldithiocarbamate was conducted to transform a part of chloromethyl groups into DTC groups. The reaction proceeded almost quantitatively and $\mathrm{ca}$. $65 \%$ of chloromethyl groups were converted to DTC groups in the resulting DCPSQ. Next, DCPSQ was treated with 1.2 equiv. of triethylamine to the remaining chloromethyl groups at $50{ }^{\circ} \mathrm{C}$ in DMF. The contents of the functional groups were estimated from the ${ }^{1} \mathrm{H} \mathrm{NMR}$ spectral data as mentioned later. The estimations showed that the formation of the ammonium salt also proceeded effectively to give the product DEAPSQ, which had $2.6 \mathrm{mmol}$ equiv./g of DTC group and $1.2 \mathrm{mmol}$ equiv./g of the ammonium salt. In a

Table II. Preparation of multi-functional grafted PSQ

\begin{tabular}{|c|c|c|c|c|c|c|c|}
\hline \multicolumn{2}{|c|}{ Conditions $^{\mathrm{a}}$} & \multicolumn{6}{|c|}{ Multi-functional PSQ grafted the block copolymer } \\
\hline $\begin{array}{l}\text { Functional } \\
\text { PSQ }\end{array}$ & $\begin{array}{c}\text { 1st Monomer } \\
\text { (2nd Monomer) }\end{array}$ & $\begin{array}{l}\text { Product }^{b} \\
\text { (Total } \\
\text { yield, \%) }\end{array}$ & $\begin{array}{c}M_{\mathrm{n}}^{\mathrm{c}} \\
\left(M_{\mathrm{w}} / M_{\mathrm{n}}\right)\end{array}$ & $\begin{array}{l}\text { Content of } 1 \mathrm{st} \\
\text { monomer unit }^{d} \\
\text { mmol equiv./g }\end{array}$ & $\begin{array}{l}\text { Content of } 2 \text { nd } \\
\text { monomer unit }^{\mathrm{d}} \\
\text { mmol equiv./g }\end{array}$ & $\begin{array}{c}\text { Content of } \\
\text { DTC group } \\
\text { mmol equiv./g }\end{array}$ & $\begin{array}{c}\text { Content of } \\
\text { functional group } \\
\text { mmol equiv./g }\end{array}$ \\
\hline \multirow[t]{2}{*}{ DEAPSQ } & $\begin{array}{c}\text { DMAA } \\
\text { (NIPAM) }\end{array}$ & $\begin{array}{c}\text { GrEAD2N } \\
(86)\end{array}$ & $\begin{array}{l}51000 \\
(2.17)\end{array}$ & 5.9 & 3.0 & 0.3 & 0.1 \\
\hline & $\begin{array}{l}\text { NIPAM } \\
\text { (DMAA) }\end{array}$ & $\begin{array}{c}\text { GrEAND2 } \\
(88)\end{array}$ & $\begin{array}{l}52000 \\
(2.08)\end{array}$ & 2.9 & 5.7 & 0.3 & 0.1 \\
\hline \multirow[t]{2}{*}{ DMAPSQ } & $\begin{array}{c}\text { DMAA } \\
\text { (NIPAM) }\end{array}$ & $\begin{array}{c}\text { GrMAD2N } \\
(85)\end{array}$ & $\begin{array}{l}48000 \\
(1.88)\end{array}$ & 5.7 & 2.9 & 0.3 & 0.1 \\
\hline & $\begin{array}{l}\text { NIPAM } \\
\text { (DMAA) }\end{array}$ & $\begin{array}{c}\text { GrMAND2 } \\
(82)\end{array}$ & $\begin{array}{l}49000 \\
(1.56)\end{array}$ & 2.9 & 5.5 & 0.3 & 0.1 \\
\hline \multirow[t]{2}{*}{ DHBPSQ } & $\begin{array}{c}\text { DMAA } \\
\text { (NIPAM) }\end{array}$ & $\begin{array}{c}\text { GrHBD2N } \\
(81)\end{array}$ & $\begin{array}{l}49000 \\
(1.63)\end{array}$ & 5.8 & 2.9 & 0.3 & 0.2 \\
\hline & $\begin{array}{l}\text { NIPAM } \\
\text { (DMAA) }\end{array}$ & $\begin{array}{c}\text { GrHBND2 } \\
(77)\end{array}$ & $\begin{array}{l}52000 \\
(1.47)\end{array}$ & 2.9 & 5.9 & 0.3 & 0.2 \\
\hline
\end{tabular}

a The graft polymerization was carried out by using 20 equiv. of DMAA or 10 equiv. of NIPAM in the presence of 17 mol $\%$ of $\mathrm{AIBN}$ to $\mathrm{DTC}$ group at $70{ }^{\circ} \mathrm{C}$ for $18 \mathrm{~h}$. The monomer concentration in the mixed solvent of DMF and ethanol was adjusted to be $2[\mathrm{M}]$. ${ }^{\mathrm{b}} \mathrm{The}$ yield was calculated thorough the graft polymerizations of two steps and based on the weights of the substrates. ${ }^{\mathrm{C}}$ Estimated by GPC [Eluent: DMF, Standard: poly(methylmethacrylates)]. ${ }^{\mathrm{d}}$ The content was based on ${ }^{1} \mathrm{H}$ NMR spectral data. 
same manner, DCPSQ was treated with $N, N$-dimethylaniline to give DMAPSQ containing $2.5 \mathrm{mmol}$ equiv./g of DTC group and $1.1 \mathrm{mmol}$ equiv./g of the salt. The $M_{\mathrm{n}} \mathrm{s}$ of DEAPSQ and DMAPSQ estimated by GPC became somewhat larger values such as 5000 compared to that of the starting DCPSQ such as 4000. The results were shown in Table I.

The graft polymerizations of DMAA and NIPAM from DEAPSQ and DMAPSQ were performed under the same thermal polymerization conditions to that reported in the previous work. ${ }^{21}$ The polymerizations progressed at $70{ }^{\circ} \mathrm{C}$ in the presence of the catalytic amount of AIBN such as $17 \mathrm{~mol} \%$ to DTC group. In this work, the feed mole ratios of DMAA and NIPAM to DTC group were adjusted to be 20 and 10 equivalents, respectively. In the polymerizations, the concentration of the monomer was fixed to be $c a .2 .5[\mathrm{M}]$ in the mixed solvents of DMF and ethanol. The first grafting of poly(DMAA) afforded the intermediary grafted PSQs. The degrees of polymerization estimated by the data of GPC and ${ }^{1} \mathrm{H}$ NMR spectra showed almost same values around 20, which was in good agreement with the theoretical value. In the cases using 10 equiv. of NIPAM to DTC group as the first monomer also proceeded successfully to give the PSQs in the high yields over $88 \%$. In addition, in the application of RAFT process, almost quantitative amount of DTC groups was recovered after the first grafting of DMAA or NIPAM. The obtained PSQs grafting the first polymer components were isolated as the insoluble parts in diethyl ether and, then, employed for the further grafting.

The graft polymerizations of the second monomers to introduce the block copolymer could be achieved as desired. The introductions of poly(NIPAM) to the PSQs having poly(DMAA) chains proceeded to graft the block copolymer, poly(DMAA)-block-poly(NIPAM), in over 91\% yield. The $M_{\mathrm{n}} \mathrm{s}$ of the resulting PSQs, GrEAD2N and GrMAD2N were 51000 and 48000, respectively. Similarly, the graft polymerizations to obtain the PSQs having poly(NIPAM)-bockpoly(DMAA) such as GrEAND2 and GrMAND2 were carried out under the same conditions. The GPC analyses showed the analogous $M_{\mathrm{n}}$ s such as 52000 for GrEAND2 and 49000 for GrMAND2 to those of GrEAD2N and GrMAD2N. In such graft polymerizations of the second monomers, the data of GPC and ${ }^{1} \mathrm{H}$ NMMR spectra demonstrated the reasonable contents of the monomer units around 20 for the grafting of DMAA and 10 for NIPAM. Furthermore, in the chromatograms of GPC for the grafted PSQs, a unimodal peak was observed.

In the preparation of the PSQ having phenol groups, the esterification of CPSQ using $m$-hydoroxybenzoic acid was carried out at first and, then, DTC groups were introduced. The esterified product, CHBPSQ, was obtained, but the isolated yield such as 52\% was lower compared to other PSQ derivatives. Such low yield may be attributed to a solubility of CHBPSQ in diethyl ether, which increased by the presence of phenol groups. The reaction of CHBPSQ with sodium $N, N$ dimethyldithiocarbamate proceeded almost quantitatively to give DHBPSQ, which had both phenol and DTC groups. The graft polymerizations of NIPAM and DMAA onto DHBPSQ were achieved under the same conditions mentioned above. By the graftings, the PSQs having phenol groups with poly(DMAA)-block-poly(NIPAM), GrHBD2N, and poly(NIPAM)-block-poly(DMAA), GrHBND2, were prepared. The degree of polymerizations at the first graftings and the second ones calculated by GPC and ${ }^{1} \mathrm{H}$ NMR spectral data were reasonable. The $M_{\mathrm{n}}$ of the PSQ grafted 20 equiv. of DMAA such as 28000 increased to 49000 for GrHBD2N after the grafting of NIPAM. In the preparation of GrHBND2, the $M_{\mathrm{n}}$ was recorded to be 52000 . The results indicated the graft polymerizations progressed effectively even when phenol groups were existed on the same PSQ backbone.

The contents of DTC group, the ammonium salts, phenol group, and the monomer units were estimated by ${ }^{1} \mathrm{H}$ NMR spectral data. In the ${ }^{1} \mathrm{H}$ NMR spectrum of DCPSQ, the signal due to the protons of methylene bonded to DTC group was detected at $4.50 \mathrm{ppm}$. The signal appeared at $4.70 \mathrm{ppm}$ was assigned to the protons of the remaining chloromethylphenyl group. After the introduction of triethylamine, the signal assigned to methyl protons was newly detected at $1.37 \mathrm{ppm}$ due to methyl protons in the spectrum of DEASPQ, although the signal at $4.70 \mathrm{ppm}$ was not shifted. The content of triethylamine moiety was calculated from the both peak areas of the signal at $4.70 \mathrm{ppm}$ and $1.37 \mathrm{ppm}$. The calculations gave almost same values. This demonstrated that the formation of the ammonium salt proceeded almost quantitatively. The peak area of the signal at $4.70 \mathrm{ppm}$ was also employed for the estimation in the case of DMAPSQ. In addition, the content of DTC group was based on the areas of two signals due to methyl protons appeared at $3.33 \mathrm{ppm}$ and $3.43 \mathrm{ppm}$. In the case of DHBPSQ, a characteristic signal was observed at $5.27 \mathrm{ppm}$, which was assigned to the methylene group bonded to ester. The proton area of the signal was used for the calculation of content of phenol group. In the grafted PSQs, the additional signals due to the monomer units were observed. In the spectra of the PSQs containing DMAA units, the peak area due to methylene protons detected at $c a$. $1.6 \mathrm{ppm}$ was usable for the calculation. The content of NIPAM unit was easily calculated by the use of the peak area of the signal at $3.86 \mathrm{ppm}$ which appeared as an easily distinguishable peak. In the grafted PSQs containing the both monomer units, the two areas mentioned above were utilized for the estimation of the contents. However, after the grafings of the monomers, the signals assigned to the functional groups became so small. This might result in inaccurate estimations to determine the contents of the functional groups. For the examples, the ${ }^{1} \mathrm{H}$ NMR spectra of DEAPSQ and GrEAD2N were shown in Figures 1 and 2, respectively.

${ }^{13} \mathrm{C}$ NMR spectrum of the grafted PSQs supported the incorporations of the functional groups and the graft chains. In the case of DHBPSQ, the presence of ester bond was demonstrated by the signal detected at $165.2 \mathrm{ppm}$ due to carbonyl group. However, unfortunately, no distinguishable signal for $N, N$-dimethylaniline moiety was found in the ${ }^{13} \mathrm{C}$ NMR spectrum of DMAPSQ. The signal of carbon for DTC group assigned to thiocarbonyl group was found at $196 \mathrm{ppm}$ in all the ${ }^{13} \mathrm{C}$ NMR spectra before grafting. After the 
a
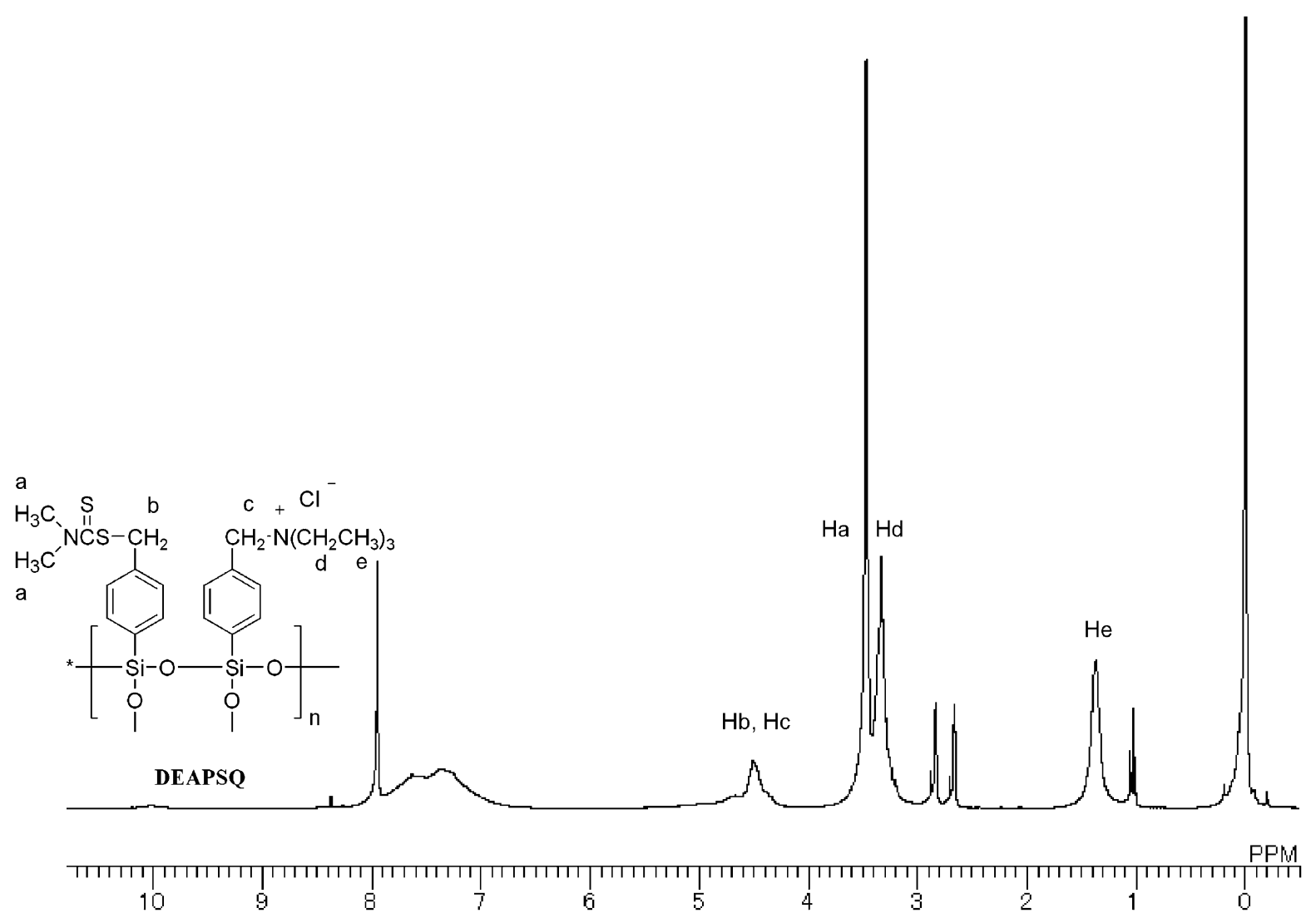

Figure 1. ${ }^{1} \mathrm{H}$ NMR spectrum $\left(\mathrm{DMF}-\mathrm{d}_{7}, 300 \mathrm{MHz}\right)$ of DEAPSQ.

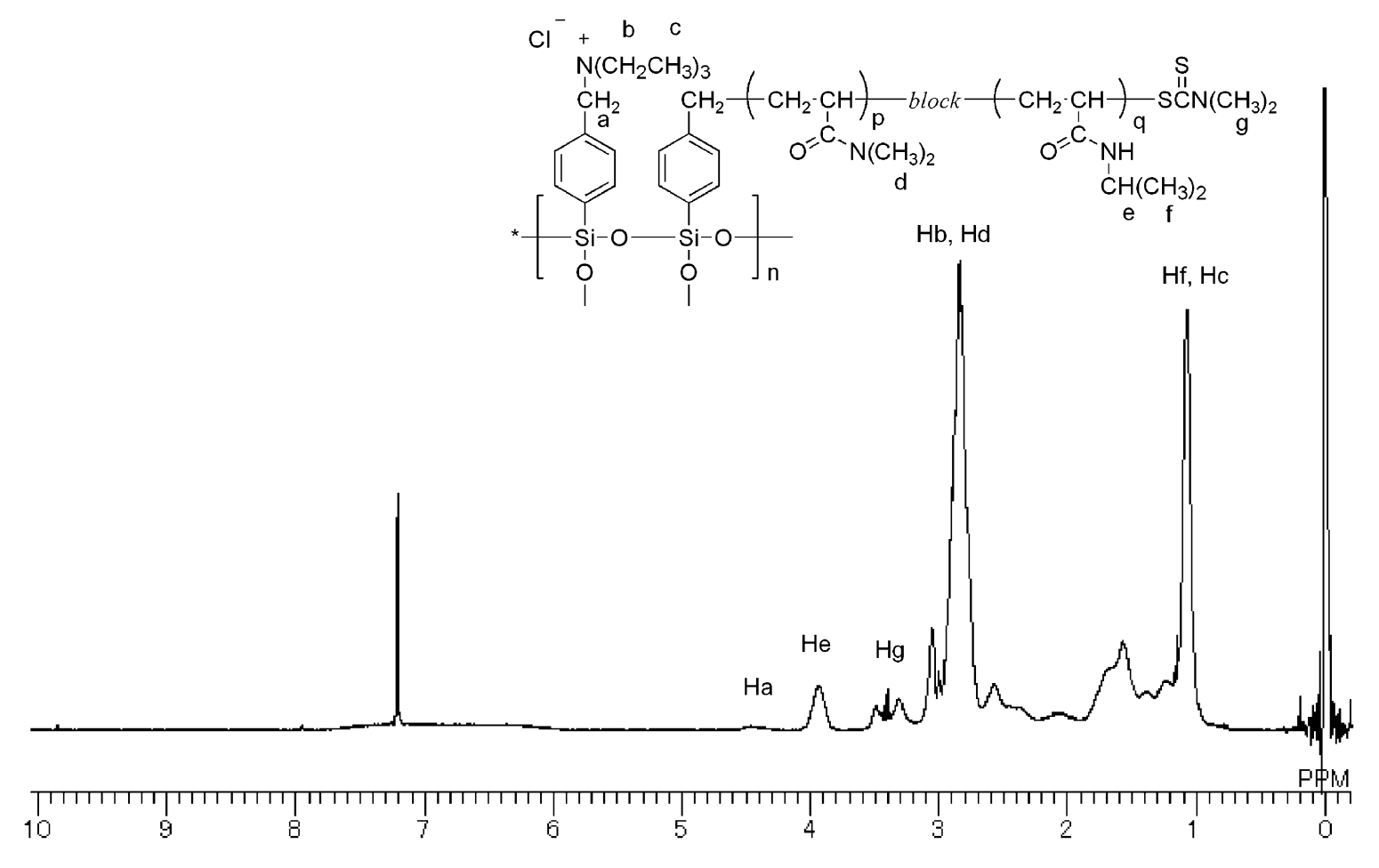

Figure 2. ${ }^{1} \mathrm{H}$ NMR spectrum $\left(\mathrm{DMF}-\mathrm{d}_{7}, 300 \mathrm{MHz}\right)$ of GrEAD2N. 
graft polymerizations of the block copolymers, the corresponding signals to DMAA and NIPAM units were observed easily. The carbon of amide group of both NIAPM and DMAA units was observed as a signal appeared at $174.6 \mathrm{ppm}$. Furthermore, the presence of the monomer units and polysiloxane structure in the grafted polysilsesquioxanes was demonstrated in the IR spectra. In the spectra, a strong absorbance at $1640 \mathrm{~cm}^{-1}$ due to amide group and that at $1100 \mathrm{~cm}^{-1}$ assigned to silicon-oxygen bond of the polysiloxane backbone were obviously observed.

Thus, the multi-functional grafted PSQs, which contained the different sequences and numbers of DMAA and NIPAM units in the graft chains, were prepared in this work, and the analytical data was listed in Table II.

\section{Thermoresponsive Behavior and Additional Property of the Grafted $P S Q$}

The previous measurement of contact angle using the coated films of the grafted PSQs on polyethylene terephtalate sheet with water drop demonstrated the clear hydrophilic property in comparison with the starting PSQ having chloromethylphenyl groups. ${ }^{21}$ In addition, the contact angles observed at $60^{\circ} \mathrm{C}$ in comparison with those at $20^{\circ} \mathrm{C}$ suggested that a hydrophobic aggregation in the graft chain occurred even in the films of the grafted PSQs. However, the film, obtained from the PSQ grafting the random copolymer of DMAA and NIPAM, GrRD2N, showed no change of contact angle at the temperatures. While, the solubility in water, which was indicated as $\% \mathrm{~T}$ observed from a visible source of $600 \mathrm{~nm}$ at $20^{\circ} \mathrm{C}$, was affected clearly according to the difference of the graft chains. When poly(DMAA) in the block copolymer was placed near the hydrophobic PSQ backbone and poly(NIPAM) was located as the end component, the solubility of the grafted PSQ in water was improved markedly. ${ }^{21}$ Whereas, the PSQs having poly(DMAA) as the end component in the graft chain, the solubility in water was reduced. Another result obtained in the evaluation of solubility in water was that the values of $\% \mathrm{~T}$ increased reasonably with the increase of content of DMAA unit in the graft chain. These demonstrated the changes of hydrophiilic environment around PSQ backbone. Analogously, the environments of the multi-functional PSQs seem to be influenced by the presences of phenol or ammonium salt moieties. Especially, the ammonium salt obtained from triethylamine was assumed to make more hydrophilic environment than that from $\mathrm{N}, \mathrm{N}$-dimethylaniline.

The thermoresponsive aggregation was evaluated by the turbidity, which was indicated as a transmittance at $600 \mathrm{~nm}$. The relationships between $\% \mathrm{~T} v s$. temperature were measured under heating and cooling, the rate of which were adjusted to be $1{ }^{\circ} \mathrm{C} / 30 \mathrm{~s}$. In Figure 3, the phase separation behavior of GrD2N, which had 20 equiv. of DMAA unit and 10 equiv. of NIPAM unit to DTC group in the graft chains of poly(DMAA)-block-poly(NIPAM), under heating were shown. The phase separation of the aqueous solution started at $34^{\circ} \mathrm{C}$ and the aggregation was completed at $\mathrm{ca} .37^{\circ} \mathrm{C}$ under heating, In cooling, \% $\mathrm{T}$ began to increase at $35^{\circ} \mathrm{C}$ and colorless solution was recovered at $30^{\circ} \mathrm{C}$. Such reversible phase separation was

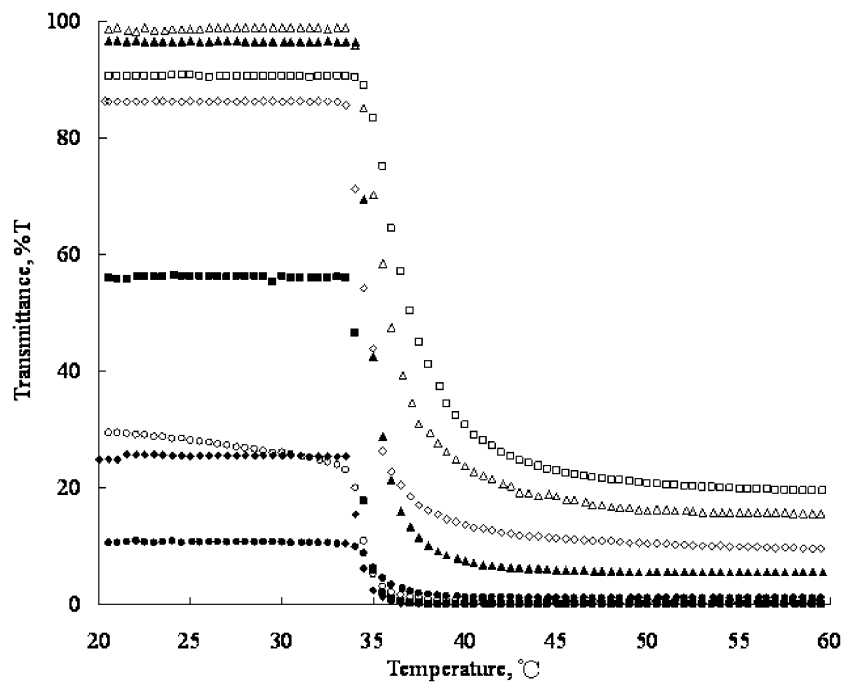

Figure 3. Temperature dependence of optical transmittance (\%T) for $1 \mathrm{wt} \%$ aqueous solution at $600 \mathrm{~nm}$ under heating: $(\bigcirc)$ GrDN, $(\diamond)$

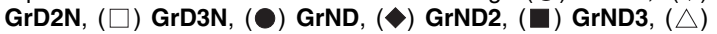
GrEAD2N, and (A) GrEAND2.

observed in all the aqueous solutions of the grafted PSQs examined in this work. However, to avoid a complicated view, the curves observed under cooling were excluded in the Figures. As mentioned above, the PSQs having poly(DMAA)block-poly(NIPAM) chains such as GrDN, GrD2N, and GrD3N usually showed a better solubility in water than those having poly(NIPAM)-block-poly(DMAA) chains such as GrND, GrND2, and GrND3. However, the same LCST such as $c a .34^{\circ} \mathrm{C}$ was recorded in all the samples. Analogously, no relationship between the content of DMAA unit, which should increase a hydrophilic property of PSQ, with LCST was observed as shown in the cases of GrDN, GrD2N, and GrD3N. On the other hand, the aggregation started at $80^{\circ} \mathrm{C}$ in the aqueous solution of GrRD2N having the random copolymer of DMAA and NIPAM, the behavior of which was not depicted here. The LCST of GrRD2N was markedly increased as predicted from the previous reports. ${ }^{28,29}$ This can explain the previous finding that no change of contact angle was detected in the measurements at $20^{\circ} \mathrm{C}$ and $60{ }^{\circ} \mathrm{C} .{ }^{21}$ Namely, the both temperatures for the measurement were lower than that of hydrophobic aggregation of GrRD2N.

The hydrophilic environment around poly(NIPAM) chains mentioned above didn't affect on LCST, but it was related with the sensitivity of the aggregation as indicated by the temperature width for the change of the phase from solution to complete gel formation. In the measurements of thermoresponsive behavior of GrDN, the change of the phase accomplished within $\mathrm{ca} .2{ }^{\circ} \mathrm{C}$ as shown in Figure 3. The temperature width for complete aggregation of GrD3N, which contained 3 times of DMAA unit compared to GrDN, under heating was $7{ }^{\circ} \mathrm{C}$. When NIPAM was grafted as the first monomer, no relationships of content of hydrophilic poly(DMAA) chain with the sensitivity was observed. In the measurements of GrND, GrND2, and GrND3, the aggregation accomplished 


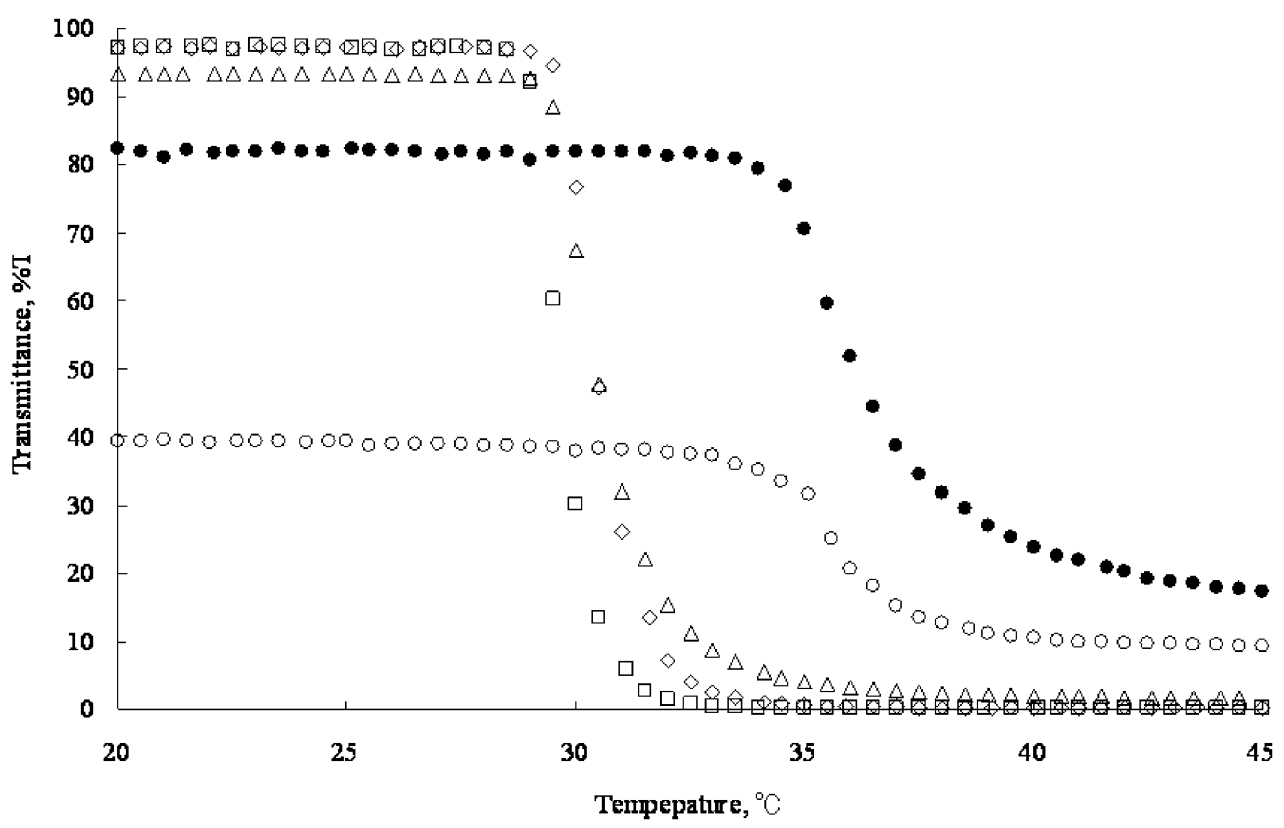

Figure 4. Temperature dependence of optical transmittance $(\% \mathrm{~T})$ at $600 \mathrm{~nm}$ under heating for 1 wt $\%$ aqueous solution of GrHBND2: $(\bigcirc)$ at $\mathrm{pH}=6$, $(0)$ at $\mathrm{pH}=12$, and for $1 \mathrm{wt} \%$ solution of GrMAND2 in water and ethanol: $(\triangle)$ at $\mathrm{pH}=3,(\square)$ at $\mathrm{pH}=7,(\diamond)$ at $\mathrm{pH}=11$.

within $2{ }^{\circ} \mathrm{C}$. Consequently, the hydrophilic property of poly(DMAA) in the block copolymer was reflected in the sensitivity of thermoresponsive phase separation only when the grafted chain was placed between the hydrophobic PSQ backbone and poly(NIPAM) component. The findings suggested that an enough part of the PSQ was required to be free from water molecules to show the completion of aggregation. Namely, it took a longer time to aggregate an enough amount of NIPAM units by moving away water molecules, when the hydrophilic DMAA units or the functional groups were existed around the PSQ backbone. This seemed to be reflected the sensitivity.

Next, the thermoresponsive behaviors of the multi-functional grafted PSQs having phenol groups or quarternary ammonium salts were examined. The measurements of $\% \mathrm{~T}$ for the aqueous solution of GrHBD2N and GrHBND2 at $25^{\circ} \mathrm{C}$ showed the effects of phenol group as shown in Figure 4. In the solution of GrHBD2N, which showed a good solubility in water by the grafting of poly(DMAA)-block-poly(NIPAM) chain, the recorded transmittances were over $80 \%$ in spite of the change of $\mathrm{pH}$ values. While, in the measurements of the solution of GrHBND2, 38\% of $\% \mathrm{~T}$ at $\mathrm{pH}=6$ became $82 \%$ at $\mathrm{pH}=12$. The later results were interpreted that phenol group as a weak acid brought $\mathrm{pH}$ responsive property into the PSQ by forming sodium salt. Furthermore, such responsibility could not be observed in the former case having the graft chains of poly(DMAA)-block-poly(NIPAM), because the PSQ, GrHBD2N, essentially showed a good solubility in water. However, such $\mathrm{pH}$ responsive solubility in water of GrHBND2 was unrelated with LCST. The starting temperatures of aggregation at $\mathrm{pH}=6$ and $\mathrm{pH}=12$ showed the same value such as $34^{\circ} \mathrm{C}$. The temperature was also in accord with the recorded LCST of the grafted PSQs having no additional functional group. In these cases, the solubility in water was also reflected in the sensitivity of the phase separation. The temperature width for the aggregation at $\mathrm{pH}=12$ showed the larger value such as $8{ }^{\circ} \mathrm{C}$ in comparison with $c a .3^{\circ} \mathrm{C}$ at $\mathrm{pH}=6$.

The PSQs introducing triethylamine, GrEAD2N and GrEAND2, showed a good solubility in water regardless of sequence of the monomer units. However, these samples also showed the same LCST to the grafted PSQs mentioned above as depicted in Figure 3. On the other hand, the PSQs having aniline moieties showed a poor solubility in water even in the PSQ having the graft chains of poly(DMAA)-block-poly(NIPAM) such as GrMAD2N. Consequently, the measurements of thermoresponsive aggregation for GrMAD2N and GrMAND2 were conducted in the mixed solvents of water and ethanol, the volume ratio of which was adjusted to be 9 to 1 . Even in these samples, no different behavior was observed in comparison with other grafted PSQs as shown in Figure 4, although LCST was fallen to $30^{\circ} \mathrm{C}$. The fall of LCST was explained by the presence of ethanol, which seemed to made a hydrophobic environment around poly(NIPAM) chain. Indeed, LCST of GrD2N, which possessed no ammonium salt moiety, became $30^{\circ} \mathrm{C}$ in the mixed solution. The results concerning the PSQs having the graft chains and ammonium salts indicated that the sequence of the monomer units and the presence of ammonium salt on PSQ backbone brought about no change of the aggregation temperature. Such findings were supported by our previous experimental facts reported on the PSQs introducing ammonium salt moieties and graft chains of poly(NIPAM). ${ }^{20}$

During the measurement of $\% \mathrm{~T}$ for the PSQs containing aniline moieties, the color of the solution faded from violet to colorless with the increase of $\mathrm{pH}$ value. In usual, such phenomena, including change of colors, have been observed in 


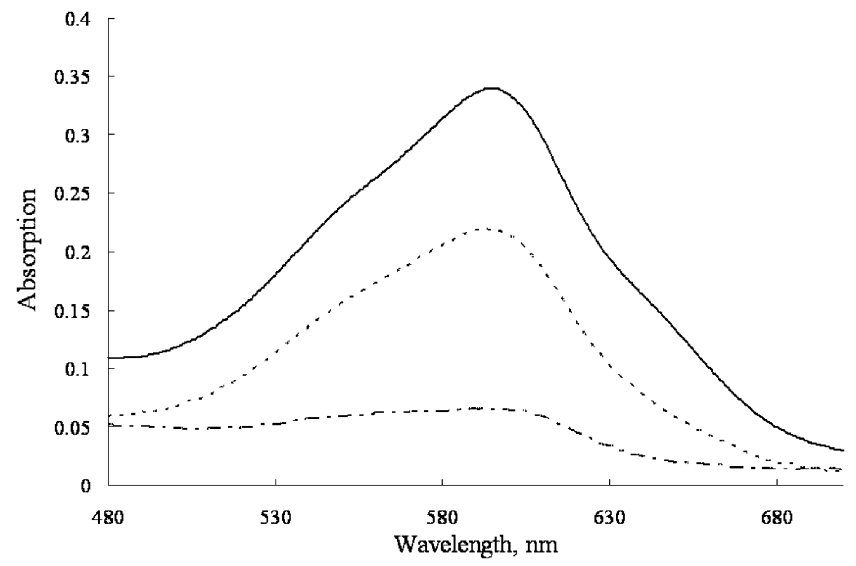

Figure 5. Relationships between $\mathrm{pH}$ and absorption of GrMAND2: ( - ) at $\mathrm{pH}=3,(\cdots)$ at $\mathrm{pH}=7$, and $(-\cdot-)$ at $\mathrm{pH}=11$.

various chromophore consisted of conjugated ammonium salt. $^{32}$ In the case of GrMAND2, a kind of chromism was provided by the formation of the simple qurternary ammonium salt as an additional function. The UV spectra, which demonstrated the changes of absorption at $20^{\circ} \mathrm{C}$, were shown in Figure 5. The absorption of 0.35 at $\mathrm{pH}=3$ was remarkably decreased to be 0.05 at $\mathrm{pH}=11$. For the adjustment of $\mathrm{pH}$ value of 3 and 11 in the mixed solvent of water and ethanol, hydrochloric acid and sodium hydroxide were employed, respectively. Such chromism showed no relation with the thermoresponsive behavior. Since, the aggregation started at $30{ }^{\circ} \mathrm{C}$ in all the solutions, of which $\mathrm{pH}$ values were adjusted to be 3, 7, and 11 as shown in Figure 4. These demonstrated that a kind of halo-chromism was presented without changing the property of thermoresponsive phase separation.

The findings on the properties of the multi-functional PSQs demonstrated that the characteristics due to the organic groups could be observed, although the contents of the groups were so small compared to those of the monomer units. In addition, the properties appeared independently without affecting the thermoresponsive behavior of the graft chains introduced on the same PSQ backbone. This may be explained by the presence of poly(NIPAM) as a block, which can act independently irrespective of environment. In other words, the presence hydrophilic monomer unit neighboring NIPAM unit retards to exclude water molecules around them in the random copolymer, but the block of NIPAM unit having no hydrophilic unit around it primarily reach a hydrophobic situation easily. Analogously, such property of a block of NIPAM unit should not be affected by the existence of the functional groups, which locate on PSQ backbone.

\section{CONCLUSIONS}

The PSQs having the block copolymers of NIPAM and DMAA, which showed several kinds of sequence and number of the monomer units, were prepared through RAFT process by the use of DTC group. Furthemore, the introduction of quarternary ammonium salt moieties or phenol groups besides the graft chains on PSQ backbone could be performed as designed to prepare the new multi-functional organic-inorganic hybrid materials. The presence of phenol groups on the PSQ backbone contributed to provide the $\mathrm{pH}$ responsive solubility in water as an additional function. The introduction of ammonium salt moieties demonstrated that the amphiphilic property of the PSQ could be controlled by the choice of amine species. In addition, the use of $\mathrm{N}, \mathrm{N}$-dimethylaniline for the formation of ammonium salt was a convenient technique to utilize the PSQ as a chromophore.

In the measurements of thermoresponsive behavior of the grafted PSQs, the sequence and number of hydrophilic DMAA units in the block copolymer showed no effect on the aggregation temperature. In the PSQs, which contained the functional groups on PSQ backbone with the graft chains, the unchanged LCST was also observed. The results demonstrated that the poly(NIPAM) chains in the copolymer aggregated efficiently even when a hydrophilic environment was formed around the block of NIPAM units. Consequently, the incorporation of other monomer units to form the random copolymer with NIPAM was required to change LCST.

The $\mathrm{pH}$ responsible solubility caused by phenol group and a kind of halo-chromism by $N, N$-dimethylaniline salt moiety were the typical examples for the preparations of multifunctional PSQ hybrid materials, in which the functions could be provided independently with thermoresposive aggregation property. In addition, the use of PSQ as a polymeric backbone was demonstrated to be a convenient and a practical method for the formation of multi-functional materials. Such information was thought to be helpful for designing a stimuli-responsive hybrid material consisted of polysiloxane structure.

Received: October 2, 2007

Accepted: October 31, 2007 Published: December 11, 2007

\section{REFERENCES}

1. R. H. Baney and X. Cao, "Silicon-Containing Polymers," R. G. Johns, W. Ando, and J. Chojnowski, Ed., Kluwer, Dordrecht, 2000.

2. M. M. Sprung and F. O. Guenther, J. Polym. Sci., 28, 17 (1958).

3. J. F. Brown, L. H. Vogt, A. Katchman, J. W. Eustance, K. M. Kaiser, and K. W. Krantz, J. Am. Chem. Soc., 82, 6194 (1960).

4. D. A. Roy and K. J. Shea, Chem. Rev., 95, 31 (1995).

5. T. Kondo, K. Yoshi, K. Horie, and M. Itoh, Macromolecules, 33, 3650 (2000).

6. J.-K. Lee, K. Char, H.-W. Rhee, H. W. Ro, D. Y. Yoo, and D. Yoon, Polymer, 42, 9085 (2001).

7. S. Yamamoto, N. Yasuda, A. Ueyama, H. Adachi, and M. Ishikawa, Macromolecules, 37, 2778 (2004).

8. C.-L. Chang and C.-C. M. Ma, J. Polym. Sci., Part A: Polym. Chem., 41, 1371 (2003).

9. P. S. Gopala Krishnan and C. He, Macromol. Chem. Phys., 204, 531 (2003).

10. J. Pyun and K. Matyjaszewski, Chem. Mater., 13, 3436 (2001).

11. K.-M. Kim, D.-K. Keum, and Y. Chujo, Macromolecules, 36, 867 (2003).

12. K. Suzuki, J. Oku, M. Takai, H. Okabayashi, and C. J. O'Connor, Polym. J., 35, 938 (2003).

13. G. Cardoen and E. B. Coughlin, Macromolecules, 37, 5123 (2004). 
14. B. X. Fu, A, Lee, and T. S. Haddad, Macromolecules, 37, 5211 (2004).

15. K. Ohno, S. Sugiyama, K. Koh, Y. Tsujii, T. Fukuda, M. Yamahiro, H. Oikawa, Y. Yamamoto, N. Ootake, and K. Watanabe, Macromolecules, 37, 8517 (2004).

16. T. Zhang, K. X. Hong Chen, and X. Yu, J. Appl. Polym. Sci., 91, 190 (2004).

17. O. Moriya, S. Yamamoto, S. Kumon, T. Kageyama, A. Kimura, and T. Sugizaki, Chem. Lett., 33, 224 (2004).

18. T. Sugizaki, M. Kashio, A. Kimura, S. Yamamoto, and O. Moriya, J. Polym. Sci., Part A: Polym. Chem., 42, 4212 (2004).

19. S. Yamamoto, T. Shimada, A. Kimura, T. Sugizaki, and O. Moriya, Polym. J., 36, 761 (2004).

20. O. Moriya, M. Kuga, S. Yamamoto, M. Kashio, A. Kamejima, and T. Sugizaki, Polymer, 47, 1837 (2006).

21. T. Masuda, S. Yamamoto, O. Moriya, M. Kashio, and T. Sugizaki, Polym. J., 39, 220 (2007).
22. J. E. Guillet, J. Macromol. Sci. Chem., A2, 1441 (1968).

23. G. H. Chen and A. S. Hoffman, Nature, 373, 49 (1995).

24. R. H. Pelton, Adv. Colloid Interface Sci., 85, 1 (2000).

25. B. Ray, Y. Isobe, K. Matsumoto, S. Habaue, Y. Okamoto, M. Kamigaito, and M. Sawamoto, Macromolecules, 37, 1702 (2004).

26. S. Meyer and W. Richtering, Macromolecules, 38, 1517 (2005).

27. D. Kuckling and S. Wohlrab, Polymer, 43, 1533 (2002).

28. Y. Kaneko, S. Nakamura, K. Sakai, A. Kikuchi, T. Aoyagi, Y. Sakurai, and T. Okano, J. Biomater. Sci. Polym. Ed., 10, 1079 (1999).

29. J. Tian, T. A. P. Seery, and R. A. Weiss, Macromolecules, 37, 9994 (2004).

30. C. Yang and Y. L. Cheng, J. Appl. Polym. Sci., 102, 119 (2006).

31. J. Chojnowski, W. Fortuniak, P. Roscizewski, W. Werel, J. Lukasiak, W. Kamysz, and R. Halasa, J. Inorg. Organometall. Polym. Mater., 16, 219 (2006).

32. Y. A. Vasilieva, D. B. Thomas, C. W. Scales, and C. L. McCormick, Macromolecules, 37, 2728 (2004). 